\title{
The Relationship between Vitamin D Status and Allergic Diseases in New Zealand Preschool Children
}

\author{
Carolyn Cairncross ${ }^{1}$, Cameron Grant ${ }^{2,3}$, Welma Stonehouse ${ }^{4}$, Cath Conlon ${ }^{1}$, Barry McDonald ${ }^{5}$, \\ Lisa Houghton ${ }^{6}$, Darryl Eyles ${ }^{7,8}$, Carlos A. Camargo Jr. ${ }^{9}$, Jane Coad ${ }^{1}$ and Pamela von Hurst ${ }^{1, *}$ \\ 1 School of Food and Nutrition, Massey University, Auckland 0632, New Zealand; \\ C.t.cairncross@massey.ac.nz (C.Ca.); c.conlon@massey.ac.nz (C.Co.); j.coad@massey.ac.nz (J.C.) \\ 2 Department of Paediatrics, University of Auckland and General Paediatrics, Auckland 1010, New Zealand; \\ cc.grant@auckland.ac.nz \\ 3 Starship Children's Hospital, Aucklan 1023, New Zealand \\ 4 CSIRO Food and Nutrition, Adelaide 5000, Australia; welma.stonehouse@csiro.au \\ 5 Institute of Natural and Mathematical Sciences, Massey University, Auckland 0632, New Zealand; \\ b.mcdonald@massey.ac.nz \\ 6 Department of Human Nutrition, University of Otago, Dunedin 9016, New Zealand; \\ lisa.houghton@otago.ac.nz \\ 7 Queensland Brain Institute, University of Queensland, Brisbane 4072, Australia; d.eyles@uq.edu.au \\ 8 Queensland Centre for Mental Health Research, Brisbane 4072, Australia \\ 9 Department of Emergency Medicine, Massachusetts General Hospital, Harvard Medical School, Boston, \\ MA 02114, USA; ccamargo@partners.org \\ * Correspondence: p.r.vonhurst@massey.ac.nz; Tel.: +64-9-213-6657
}

Received: 23 March 2016; Accepted: 20 May 2016; Published: 1 June 2016

\begin{abstract}
Recent research on vitamin D in young children has expanded from bone development to exploring immunomodulatory effects. Our aim was to investigate the relationship of vitamin D status and allergic diseases in preschool-aged children in New Zealand. Dried capillary blood spots were collected from 1329 children during late-winter to early-spring for 25(OH)D measurement by LC-MS/MS. Caregivers completed a questionnaire about their child's recent medical history. Analysis was by multivariable logistic regression. Mean 25(OH)D concentration was 52(SD19) nmol/L, with $7 \%$ of children $<25 \mathrm{nmol} / \mathrm{L}$ and $49 \%<50 \mathrm{nmol} / \mathrm{L}$. Children with $25(\mathrm{OH}) \mathrm{D}$ concentrations $\geqslant 75 \mathrm{nmol} / \mathrm{L}$ $(n=29)$ had a two-fold increased risk for parent-report of doctor-diagnosed food allergy compared to children with 25(OH)D 50-74.9 nmol/L (OR = 2.21, 1.33-3.68, $p=0.002)$. No associations were present between 25(OH)D concentration and presence of parent-reported eczema, allergic rhinoconjunctivitis or atopic asthma. Vitamin D deficiency was not associated with several allergic diseases in these New Zealand preschool children. In contrast, high 25(OH)D concentrations were associated with a two-fold increased risk of parental-report food allergy. This increase supports further research into the association between vitamin D status and allergic disease in preschool children.
\end{abstract}

Keywords: vitamin D; children; allergic disease; New Zealand

\section{Introduction}

Vitamin D research in young children has previously concentrated on skeletal health including rickets. Recent discoveries of an immune modulation role for vitamin $\mathrm{D}$ has led to the investigation of associations of vitamin D status with a number of immune mediated childhood illnesses, including auto-immune, atopic and infectious conditions [1-3]. Few cross-sectional studies have explored the relationship of allergic diseases with vitamin $\mathrm{D}$ status, particularly in preschool aged children.

Morbidity from childhood allergic diseases can be high and includes diminished quality of life and increased health costs for the child, their family and the community [4]. New Zealand children 
have amongst the highest rates of eczema, allergic rhinoconjunctivitis and asthma in the world [5,6]. Exaggerated immune responses to certain food proteins and associated anaphylaxis have increased over the past two decades in neighbouring Australia and worldwide [7].

The immune-modulatory actions of vitamin $\mathrm{D}$ affect both the innate and adaptive components of the immune system, and may offer potential targets for prevention or treatment of allergic diseases [8]. Research suggests the active form of vitamin $\mathrm{D}, 1,25(\mathrm{OH})_{2} \mathrm{D}$, contributes to the immune system through mechanisms that modulate immunologic tolerance, suppress pro-allergic immune responses, maintain the integrity of the epithelial barrier and reduce susceptibility to infection [9-11]. Animal model studies show evidence for a vitamin $\mathrm{D}$ mediated enhanced T helper $2\left(\mathrm{Th}_{2}\right)$ cell antigen response by two pathways; firstly by shifting the $\mathrm{T}$ lymphocyte balance toward $\mathrm{Th}_{2}$ cells through the inhibition of $\mathrm{Th}_{1}$ cells and secondly, through increased production of $\mathrm{Th}_{2}$ cells through the differentiation of naive T-Cells into $\mathrm{Th}_{2}$ cells [12,13]. A down regulation of the $\mathrm{Th}_{2}$-driven immune response inhibits skin barrier function [14] and the production of the $\mathrm{Th}_{17}$ cytokines allied with asthma severity [15]. For food allergy, it has been hypothesised that the combined effect of vitamin D deficiency and infections decreases the intestinal barrier integrity [16], which allows low doses of food protein the ability to infiltrate the immune system, leading to increased immunoglobulin E (IgE) production by beta-cells and allergenic $\mathrm{Th}_{2}$ immune responses [17].

With New Zealand preschool children having a high burden of allergic disease and living in a country with abundant sunshine yet high population rates of vitamin D deficiency, the aim of this study was to investigate the relationship between vitamin D status and prevalence of allergic diseases-eczema, food allergy, allergic rhinoconjunctivitis and atopic asthma-in a self-selected sample of New Zealand preschool children aged 2 to $<5$ years using 25(OH)D concentration measured on dried blood spot.

\section{Materials and Methods}

\subsection{Study Design and Participants}

Participants (1329) in this cross-sectional study were preschool children aged between 2 and $<5$ years of age recruited from 17 cities and towns throughout New Zealand (latitude $35^{\circ}-46^{\circ} \mathrm{S}$ ). Ethical approval was granted by the Health and Disability Ethics Committee, Northern Region, reference number NTX/12/04/036, and a parent or caregiver of each participant provided written informed consent for the participation of their child in the study.

\subsection{Data Collection}

Blood samples were obtained from enrolled children by trained staff at 49 participating community pharmacies as well as the nutrition clinics at Massey University, Auckland, and the University of Otago, Dunedin from August to October (late-winter to early-spring), 2012. A capillary blood sample from a finger prick was obtained from each child using paediatric lancets. Blood was dropped onto a pre-stamped circle on Whatman 305 filter paper and allowed to air dry for a minimum of one hour. All samples were stored at room temperature prior to analysis at Queensland Brain Institute, Brisbane, Australia, for measurement of $25(\mathrm{OH}) \mathrm{D}$ concentration.

Parents or caregivers completed a 59-item questionnaire, either online (www.surveymonkey.com) or paper format, on basic demographics, recent health history and factors associated with vitamin $\mathrm{D}$ status. All identified ethnicities for the child were listed by caregivers, with ethnicity then assigned using the following prioritisation; Māori, then Pacific, then Other, then European [18]. Caregivers rated their child's skin colour on a six-point scale (very fair, fair, medium, olive, dark and very dark). This was then collapsed into 3 skin colour categories (very fair-fair, medium, olive dark-very dark).

Caregivers were asked if their child attended formal preschool education facilities such as daycare, preschool or kindergarten. For dietary sources of vitamin D, use of supplements containing vitamin $\mathrm{D}$ and cod liver oil was determined, along with consumption of milks. A list of common milks and 
those low-fat milks fortified with vitamin D was provided, along with a free-text option for other milks consumed. Vitamin D fortified cow's milk formula marketed to young children was defined as toddler milk. Maternal education was classified as no secondary qualifications, secondary qualifications or post-secondary qualifications.

\subsection{Measurement of $25(\mathrm{OH}) \mathrm{D}$ Concentrations}

The analytical method, in brief, involves a derivatising agent combined with liquid chromatography tandem mass spectrometry [19]. The assay measured both $25(\mathrm{OH}) \mathrm{D}_{2}$ and $25(\mathrm{OH}) \mathrm{D}_{3}$, with results described as total $25(\mathrm{OH}) \mathrm{D}$. Precise $3.2 \mathrm{~mm}$ whole blood punches, equivalent to $3.2 \mu \mathrm{L}$ of whole blood, were obtained from each dried blood spot (DBS). As 25(OH)D is excluded from erythrocytes, the following equation was used to correct for the haematocrit fraction in serum of children in the preschool age group ( 0.41 for girls and 0.45 for boys) [20]:

$$
\text { Plasma }[25(\mathrm{OH}) \mathrm{D}](\mathrm{nM})=\operatorname{DBS}[25(\mathrm{OH}) \mathrm{D}](\mathrm{nM}) /(1-\text { haematocrit fraction })
$$

\subsection{Disease Outcome Measures}

Eczema, allergic rhinoconjunctivitis and atopic asthma were defined by parental report using the modules of the ISAAC questionnaire for children aged 6-7 years [5]. Eczema was defined as an itchy rash in the last 12 months affecting various body sites. Allergic rhinoconjunctivitis was defined as sneezing or runny nose symptoms in the last 12 months accompanied by itchy watery eyes. Atopic asthma was defined as wheezing or whistling in the chest in the last 12 months combined with report of eczema and/or food allergy. Doctor diagnosed food allergy was defined as a caregiver answering positively to the initial question "has your child ever had food allergy?" and then subsequently to the question "was your child's allergy confirmed or diagnosed by a doctor?"

\subsection{Statistical Analyses}

Dried blood spot 25(OH)D concentrations were categorised into 4 groups; <25, 25 to 49.9 , 50 to 74.9 and $\geqslant 75 \mathrm{nmol} / \mathrm{L}$. This grouping is consistent with the variation in definitions for vitamin $\mathrm{D}$ deficiency [21]. The association between the presence of each disease outcome and the categorised $25(\mathrm{OH}) \mathrm{D}$ concentration was investigated using univariable and multivariable logistic regression analysis, and reported using $\mathrm{OR}$ and $95 \% \mathrm{CI}$. The reference $25(\mathrm{OH}) \mathrm{D}$ category used in logistic regression was 50 to $74.9 \mathrm{nmol} / \mathrm{L}$ [21]. Analysis by linear regression was also carried out. As the results did not differ, only the logistic regression results are presented. Differences between disease outcome in mean $25(\mathrm{OH}) \mathrm{D}$ concentration were determined using Independent $t$-tests.

Demographic and environmental risk factors were considered as potential confounders in a logistic regression model for each disease outcome. Those confounding variables with a $p$ value of $<0.20$ in one predictor model analysis were entered into the logistic regression model. Those variables of non-significance were removed singly using a backwards stepwise method. The resultant confounders varied according to disease outcome. If a variable was a significant confounder for one disease outcome it was included in the multivariable logistic regression analysis for all disease outcomes to avoid unintentional bias in estimation of the relationship between disease outcome and dried blood spot 25(OH)D concentration. Each disease outcome model was also subsequently adjusted for confounding variables specific to each condition. Independent associations of $25(\mathrm{OH}) \mathrm{D}$ concentration with diseases outcomes were described using odds ratios (OR) and 95\% confidence intervals (CI).

Interaction effects were tested for each disease outcome. No significant interactions were seen. The presence of interaction was assessed using two methods, firstly through logistic regression models where the variable was multiplied by $25(\mathrm{OH}) \mathrm{D}$ and significance calculated, and secondly, through generation of scatterplot of response versus $25(\mathrm{OH}) \mathrm{D}$ with smoother lines. 
All analyses were performed with the Statistical Package for the Social Sciences (SPSS 21.0 (IBM Corp., Armonk, NY, USA)). All tests with statistical significance were determined by $p<0.05$.

\section{Results}

\subsection{Participant Characteristics}

The participant characteristics are presented in Table 1. The mean age of the children was 41 months (range 24 to 60 months), with the majority being of NZ European ethnicity (70\%), attending daycare (84\%) and having a mother with higher educational qualifications (81\%). Almost one-third of children (29\%) consumed a supplement containing vitamin D or cod liver oil while $6 \%$ reported drinking toddler milk. The mean dried blood spot $25(\mathrm{OH}) \mathrm{D}$ concentration was $52 \mathrm{nmol} / \mathrm{L}$ (range 5 to $173 \mathrm{nmol} / \mathrm{L})$.

Table 1. Participant characteristics by dried blood spot 25(OH)D categories.

\begin{tabular}{|c|c|c|c|c|c|}
\hline \multirow{2}{*}{ Variable } & \multirow{2}{*}{$n(\%)$} & \multicolumn{4}{|c|}{ 25(OH)D Categories $(\mathrm{nmol} / \mathrm{L}) n(\%)$} \\
\hline & & $<25$ & 25 to 49.9 & 50 to 74.9 & $\geqslant 75$ \\
\hline Total & 1329 & $86(7)$ & $556(42)$ & $541(41)$ & $146(11)$ \\
\hline Mean $(95 \% \mathrm{CI})(\mathrm{nmol} / \mathrm{L})$ & $52(19)$ & $19(18-20)$ & $39(39-40)$ & $61(60-61)$ & $87(85-90)$ \\
\hline Median & 51 & 20 & 40 & 60 & 82 \\
\hline Interquartile Range (IQ) & 25 & 7 & 12 & 12 & 14 \\
\hline \multicolumn{6}{|c|}{ Age (years) } \\
\hline 2 years old & $496(37)$ & $30(6)$ & $223(45)$ & $183(37)$ & $60(12)$ \\
\hline 3 years old & $448(34)$ & $25(6)$ & $180(40)$ & $194(43)$ & $49(11)$ \\
\hline 4 years old & $385(29)$ & $31(8)$ & $153(40)$ & $164(43)$ & $37(10)$ \\
\hline \multicolumn{6}{|c|}{ Gender } \\
\hline Female & $648(49)$ & $51(8)$ & $296(46)$ & $248(38)$ & $53(8)$ \\
\hline Male & $681(51)$ & $35(5)$ & $260(38)$ & $293(43)$ & $93(14)$ \\
\hline \multicolumn{6}{|c|}{ Ethnicity } \\
\hline NZ European & $926(70)$ & $32(3)$ & $378(41)$ & $401(43)$ & $115(12)$ \\
\hline Māori & $174(13)$ & $16(9)$ & $74(43)$ & $66(38)$ & $18(10)$ \\
\hline Pacific & $44(3)$ & $10(23)$ & $21(48)$ & $12(27)$ & $1(2)$ \\
\hline Other non-European & $185(14)$ & $28(15)$ & $83(45)$ & $62(34)$ & $12(7)$ \\
\hline \multicolumn{6}{|c|}{ Skin colour-parental report } \\
\hline Very fair-fair & $767(58)$ & $27(4)$ & $339(44)$ & $313(41)$ & $88(11)$ \\
\hline Medium & 445 (33) & $29(7)$ & $172(39)$ & $193(43)$ & $51(11)$ \\
\hline Olive-very dark & $17(9)$ & $30(26)$ & $45(38)$ & $35(30)$ & $7(6)$ \\
\hline \multicolumn{6}{|c|}{ Attend formal daycare } \\
\hline Yes & $1137(86)$ & $71(6)$ & $464(41)$ & $473(42)$ & $129(11)$ \\
\hline No & $192(14)$ & $15(8)$ & $92(48)$ & $68(35)$ & $17(9)$ \\
\hline \multicolumn{6}{|c|}{ Vitamin D supplement use * } \\
\hline Yes & $253(19)$ & $6(2)$ & $78(31)$ & $131(52)$ & $38(15)$ \\
\hline No & $1076(81)$ & $80(7)$ & $478(44)$ & $410(38)$ & $108(10)$ \\
\hline \multicolumn{6}{|c|}{ Drinks toddler milk } \\
\hline Yes & $80(6)$ & $0(0)$ & $20(25)$ & $44(55)$ & $16(20)$ \\
\hline No & $1249(94)$ & $86(7)$ & $536(43)$ & $497(40)$ & $130(10)$ \\
\hline \multicolumn{6}{|c|}{ Maternal-education qualifications } \\
\hline No secondary & $59(4)$ & $20(34)$ & $23(39)$ & $13(22)$ & $3(5)$ \\
\hline Secondary & $98(15)$ & $10(5)$ & $93(47)$ & 77 (39) & $18(9)$ \\
\hline Post-secondary & $1072(81)$ & $56(5)$ & $440(41)$ & $451(42)$ & $125(12)$ \\
\hline
\end{tabular}

Stepwise regression modelling confirmed 7 factors to be associated with disease outcome. These 7 factors were included as potential confounders in all disease outcome analyses. These 
factors were gender, ethnicity, skin colour, daycare attendance, usage of vitamin D supplements, consumption of toddler milk (vitamin D fortified cow's milk formula marketed to young children) and maternal education.

\subsection{Disease Outcomes}

There was a variation in prevalence of the allergic diseases in the participants of this study compared those from national samples of children aged 6 to 7 years. Prevalence was higher for eczema ( $23 \%$ vs. $17 \%$ ) and atopic asthma (32\% vs. $22 \%)$, while similar for allergic rhinoconjunctivitis (10\% vs. 11\%) [5]. Rates of food allergy in New Zealand have yet to be determined, however the $12 \%$ prevalence of parental-report doctor-diagnosed food allergy in this study reflects epidemiological studies from neighbouring Australia which estimate food allergy rates of approximately 10\% [22,23] (Table 2).

Table 2. Prevalence and odds ratios for allergic diseases by dried blood spot 25(OH)D concentration.

\begin{tabular}{|c|c|c|c|c|c|}
\hline \multirow{2}{*}{$\begin{array}{l}\text { Allergic Disease 25(OH)D } \\
\text { Concentration (nmol/L) }\end{array}$} & \multirow{2}{*}{$n$} & \multicolumn{2}{|c|}{ Unadjusted } & \multicolumn{2}{|c|}{ Adjusted * } \\
\hline & & OR $(95 \% \mathrm{CI})$ & $p$ Value & OR $(95 \% \mathrm{CI})$ & $p$ Value \\
\hline \multicolumn{6}{|c|}{ Atopic asthma $(n=420)$} \\
\hline 25 to 49.9 & 184 & $1.16(0.90,1.49)$ & 0.26 & $1.19(0.91,1.55)$ & 0.21 \\
\hline 50 to 74.9 & 162 & 1.00 & - & 1.00 & - \\
\hline$\geqslant 75$ & 49 & $1.18(0.80,1.75)$ & 0.40 & $1.13(0.76,1.69)$ & 0.55 \\
\hline \multicolumn{6}{|c|}{ Eczema $(n=299)$} \\
\hline$<25$ & 15 & $0.78(0.43,1.42)$ & 0.42 & $0.66(0.34,1.29)$ & 0.22 \\
\hline 25 to 49.9 & 132 & $1.15(0.87,1.53)$ & 0.33 & $1.20(0.92,1.55)$ & 0.26 \\
\hline 50 to 74.9 & 115 & 1.00 & - & 1.00 & - \\
\hline$\geqslant 75$ & 37 & $1.26(0.82,1.93)$ & 0.29 & $1.23(0.79,1.89)$ & 0.36 \\
\hline \multicolumn{6}{|c|}{ Food allergy $(n=153)$} \\
\hline$<25$ & 4 & $0.45(0.16,1.27)$ & 0.13 & $0.45(0.15,1.36)$ & 0.16 \\
\hline \multicolumn{6}{|c|}{ Allergic rhinoconjunctivitis $(n=139)$} \\
\hline$<25$ & 14 & $1.91(1.01,3.63)$ & 0.05 & $1.82(0.89,3.72)$ & 0.10 \\
\hline 25 to 49.9 & 56 & $1.10(0.74,1.64)$ & 0.64 & $1.14(0.75,1.72)$ & 0.54 \\
\hline 50 to 74.9 & 50 & 1.00 & - & 1.00 & - \\
\hline$\geqslant 75$ & 19 & $1.47,(0.84,2.58)$ & 0.18 & $1.45(0.82,2.58)$ & 0.20 \\
\hline
\end{tabular}

*: Adjusted for gender, ethnicity, skin colour, daycare attendance, vitamin D supplement and toddler milk usage, maternal education level. OR odds ratio, CI confidence interval.

No significant difference in mean $25(\mathrm{OH}) \mathrm{D}$ concentration was seen for children with and without eczema (53 vs. $52 \mathrm{nmol} / \mathrm{L}, p=0.50$ ), allergic rhinoconjunctivitis (52 vs. $52 \mathrm{nmol} / \mathrm{L}, p=0.94$ ) and atopic asthma (52 vs. $52 \mathrm{nmol} / \mathrm{L}, p=0.98)$. In contrast, children with food allergy had a higher mean 25(OH)D concentration than those who did not (56 vs. $52 \mathrm{nmol} / \mathrm{L}, p=0.007$ ).

In comparison with children with a $25(\mathrm{OH}) \mathrm{D}$ concentration of 50 to $74.9 \mathrm{nmol} / \mathrm{L}$, the odds of doctor diagnosed food allergy were increased for children with a $25(\mathrm{OH}) \mathrm{D}$ concentration $\geqslant 75 \mathrm{nmol} / \mathrm{L}$ (OR 2.21, 95\%CI 1.33-3.68, $p=0.002$ ). In comparison with children with a $25(\mathrm{OH}) \mathrm{D}$ concentration of 50 to $74.9 \mathrm{nmol} / \mathrm{L}$, the odds of eczema, allergic rhinoconjunctivitis or atopic asthma were neither increased nor decreased with children with higher or lower 25(OH)D concentrations (Table 2).

\section{Discussion}

In this cross-sectional study of 1329 children aged 2 to $<5$ years, higher concentrations of 25(OH)D were associated with an increased risk of parent-reported doctor-diagnosed food allergy. No association was evident between $25(\mathrm{OH}) \mathrm{D}$ concentration and the odds of eczema, allergic rhinoconjunctivitis and atopic asthma.

Other observational studies that have enrolled preschool aged children and investigated associations of vitamin D status with eczema and asthma report contradictory findings. Increased 
eczema prevalence and severity have been associated with both lower [24-28] and higher [29] 25(OH)D concentrations. An inverse correlation of $25(\mathrm{OH}) \mathrm{D}$ concentration and asthma prevalence in children attending hospital in Denver [30] and Sweden [31] is in contrast to the lack of association of 25(OH)D and asthma found in Massachusetts [32], while mean 25(OH)D concentrations were lower in children with asthma compared to controls in Egyptian [33], Quatari [34] and Turkish hospitals [35]. In recent supplementation trials of vitamin D and asthma parameters, no change was seen in Irish school children compared to placebo [36] while improvements were noted in Japanese schoolchildren [37]. Direct comparison of the data from our study that shows no association of $25(\mathrm{OH}) \mathrm{D}$ with the odds of eczema and atopic asthma is difficult because the inclusion of infants and adolescents in these other study samples, differences in diagnostic criteria used to define eczema and asthma and in the prevalence of these diseases in the populations studied.

The diagnosis of asthma in very young children can be challenging and lack of diagnosis by a doctor is a limitation of the current study. As a proxy of doctor diagnosis, parents were asked "which asthma medicines has your child used?" as these medications are required to be prescribed by a medical professional. Results of logistic regression analysis for the children with atopic asthma who reported asthma medication usage also found no association with $25(\mathrm{OH}) \mathrm{D}$ concentration. Diagnosis of asthma by a medical professional is recommended for future research studies involving preschool children.

To date few studies have directly investigated associations between disease prevalence and $25(\mathrm{OH}) \mathrm{D}$ concentration. In infants, vitamin D insufficiency is associated with an increased risk of challenge proven peanut/egg allergy [38] and vitamin D deficiency increased the risk of sensitization to food allergens, particularly to milk and wheat [39]. These findings are in contrast to our study finding of increased risk of food allergy and $25(\mathrm{OH}) \mathrm{D}$ concentrations $\geqslant 75 \mathrm{nmol} / \mathrm{L}$. This finding needs to be considered in light of the imprecise nature of parental-report of this cross-sectional study compared to clinical measurement criteria, the differences in ages, ethnicity and country of origin of the enrolled children and dried blood spot measurement of $25(\mathrm{OH}) \mathrm{D}$ compared to serum $25(\mathrm{OH}) \mathrm{D}$. In addition, genotype was not assessed in our study, with recent evidence polymorphisms associated with vitamin $\mathrm{D}$ binding protein concentrations reduce the relationship between low $25(\mathrm{OH}) \mathrm{D}$ concentrations and food allergy [40].

Conflicting findings have been reported from observational studies of the relationship between vitamin D status and allergic rhinoconjunctivitis. There was no association between $25(\mathrm{OH}) \mathrm{D}$ concentration and allergic rhinitis in studies of adults in Korea [41] and children in Qatar [42] while higher rates of vitamin D deficiency were observed in Iranian adults with allergic rhinitis compared to population controls [43]. In contrast, for children and adults in the US, the prevalence of allergic rhinitis increases as serum 25(OH)D concentration increased [44]. Birth cohort studies report both inverse and null associations of early-life measures of vitamin D status with childhood allergic rhinitis [45-47]. The results of this study are similar to those in Korea [41] and Qatar [42]. Although non-significant $(p=0.05)$, the observation of a small, increased risk of allergic rhinoconjunctivitis for children with $25(\mathrm{OH}) \mathrm{H}$ concentrations below $25 \mathrm{nmol} / \mathrm{L}$ compared to the reference category reflect findings from Iranian adults [43] and birth cohort studies [46].

This was a relatively large study of free-living healthy children enrolled from a number of centres throughout the country. Study limitations include the cross-sectional nature, which can identify associations but not establish causality and the proportion of children with $25(\mathrm{OH}) \mathrm{D}<25 \mathrm{nmol} / \mathrm{L}$. There is no capacity within a study of this design to confirm the presence or absence or severity of each of these parental-reported diagnoses. Use of the ISAAC questionnaire for children aged 6-7 years of age in this preschool age group may affect the prevalence of disease, for example, the challenging diagnosis of asthma in very young children compared to older children. The diseases were not confirmed by the diagnosis of a doctor nor the presence of intermittent or perennial symptoms. Thus, the estimation of prevalence of each allergic disease will be imprecise due to the nature of parental recall and report. This imprecise measurement is likely to reduce the capacity to identify any associations between vitamin D status and disease risk. Our study finding of increased risk of food 
allergy for children with $25(\mathrm{OH}) \mathrm{D} \geqslant 75 \mathrm{nmol} / \mathrm{L}$ needs to be considered in light of this study limitation and the small number of children with doctor-diagnosed food allergy, as it is not known whether high $25(\mathrm{OH}) \mathrm{D}$ concentrations cause a higher prevalence of food allergy or whether presence of food allergy and higher $25(\mathrm{OH}) \mathrm{D}$ concentration are due to a separate unrelated factor. Although the use of dried blood spots to measure $25(\mathrm{OH}) \mathrm{D}$ concentration enabled a large sample size in a vulnerable population, there may be limitations in comparison to studies using serum blood samples. However, good correlation and reliability have been reported between $25(\mathrm{OH}) \mathrm{D}$ concentrations from dried blood spot and serum samples in previous studies [48-50]. Bias in our recruitment strategy of self-selected participants through email resulted in a sample group of higher socioeconomic status and maternal education level than has been reported nationally [51,52]. The higher numbers of enrolled children with eczema and asthma compared to national samples may have been due bias in our advertising material which sought children to investigate the links between vitamin D and these diseases, and limits generalisation of our findings to the overall preschool population.

Findings from birth cohort studies and from animal models suggest that the immune system tolerance and microbial bacterial environment may be sensitive to vitamin $D$ status at a critical time period in pregnancy and/or early life, both to deficiency and excess [16,53]. Longitudinal study designs are necessary to fully understand the relationship between vitamin D status and allergic diseases, ideally from pregnancy onwards. Randomised controlled trials are needed to determine if the risk of atopic disease is altered by vitamin D supplementation, such as the current VITALITY trial in young children [54].

\section{Conclusions}

In this study of 1329 children aged between 2 and $<5$ years, there was no association between vitamin $\mathrm{D}$ status and parental-reported prevalence of eczema, atopic asthma or allergic rhinoconjunctivitis. Children with $25(\mathrm{OH}) \mathrm{D}$ concentrations $\geqslant 75 \mathrm{nmol} / \mathrm{L}$ had a two-fold increased risk of parental-reported, doctor-diagnosed food allergy. With the high rates of allergic diseases in young New Zealand children, further investigation into the relationship of these diseases with vitamin $D$ status should be a research priority.

Acknowledgments: We would like to thank the 1329 participants and their families, Annie Judkins and Claudine Harvey (Newton Health Services), Waitemata DHB nurses, preschool nurses from Te Puna Haora and Jenny McKenzie (University of Otago) for their assistance in testing the children, study office and testers Cherie Wong, Peter Cairncross and Sherina Holland (Massey University). We particularly wish to acknowledge the generosity of the pharmacist who allowed their premises to be used as testing centres.

Author Contributions: C.Ca.-obtained ethics approval, project leader, recruited pharmacies and participants, designed testing protocols with advice from D.E., carried out fingerprick tests, did statistical analysis, drafted the manuscript. B.M. supervised statistical analysis. L.H. recruited pharmacies and tested children. C.Co. tested children. D.E. analysed dried blood spots for 25(OH)D concentration. P.H. principal investigator, conceived research project and obtained funding. All authors were involved in the design of the questionnaire. All authors were involved in revising the manuscript and all read and approved the final manuscript.

Conflicts of Interest: The authors declare no conflict of interest.

\section{Abbreviations}

The following abbreviations are used in this manuscript:

$\begin{array}{ll}\text { LC-MS } / M S & \text { liquid chromatography with tandem mass-spectrometer } \\ \text { 25(OH)D } & \text { 25 hydroxyvitamin D } \\ 1-25(\mathrm{OH})_{2} \mathrm{D} & \text { 1,25 di-hydroxyvitamin D } \\ \mathrm{Th}_{2} & \text { T helper 2 cells } \\ \mathrm{IgE} & \text { immunoglobulin E } \\ \mathrm{DBS} & \text { dried blood spot }\end{array}$




\section{References}

1. Bener, A.; Alsaied, A.; Al-Ali, M.; Al-Kubaisi, A.; Basha, B.; Abraham, A.; Guiter, G.; Mian, M. High prevalence of vitamin D deficiency in type 1 diabetes mellitus and healthy children. Acta Diabetol. 2009, 46, 183-189. [CrossRef] [PubMed]

2. Lerner, A.; Shapira, Y.; Agmon-LYeevin, N.; Pacht, A.; Ben-Ami, S.D.; López, H.M.; Sanchez-Castanon, M.; Shoenfeld, Y. The clinical significance of $25 \mathrm{OH}$-vitamin D status in celiac disease. Clin. Rev. Allergy Immunol. 2012, 42, 322-330. [CrossRef] [PubMed]

3. Hollams, E.M.; Hart, P.H.; Holt, B.J.; Serralha, M.; Parsons, F.; de Klerk, N.H.; Zhang, G.; Sly, P.D.; Holt, P.G. Vitamin D and atopy and asthma phenotypes in children: A longitudinal cohort study. Eur. Respir. J. 2011, 38, 1320-1327. [CrossRef] [PubMed]

4. Marklund, B.; Ahlstedt, S.; Nordström, G. Health-related quality of life in food hypersensitive schoolchildren and their families: Parents' perceptions. Health Qual. Life Outcomes 2006, 4, 48-60. [CrossRef] [PubMed]

5. Asher, M.I.; Montefort, S.; Björkstén, B.; Lai, C.K.; Strachan, D.P.; Weiland, S.K.; Williams, H.; ISAAC Phase Three Study Group. Worldwide time trends in the prevalence of symptoms of asthma, allergic rhinoconjunctivitis, and eczema in childhood: ISAAC Phases One and Three repeat multicountry cross-sectional surveys. Lancet 2006, 368, 733-743. [CrossRef]

6. Masoli, M.; Fabian, D.; Holt, S.; Beasley, R.; Global Initiative for Asthma (GINA) Program. The global burden of asthma: Executive summary of the GINA Dissemination Committee report. Allergy 2004, 59, 469-478. [CrossRef] [PubMed]

7. Liew, W.K.; Williamson, E.; Tang, M.L. Anaphylaxis fatalities and admissions in Australia. J. Allergy Clin. Immunol. 2009, 123, 434-442. [CrossRef] [PubMed]

8. Mathieu, C.; Adorini, L. The coming of age of 1,25-dihydroxyvitamin $\mathrm{D}_{3}$ analogs as immunomodulatory agents. Trends Mol. Med. 2002, 8, 174-179. [CrossRef]

9. Benson, A.A.; Toh, J.A.; Vernon, N.; Jariwala, S.P. The role of vitamin D in the immunopathogenesis of allergic skin diseases. Allergy 2012, 67, 296-301. [CrossRef] [PubMed]

10. Kong, J.; Zhang, Z.; Musch, M.W.; Ning, G.; Sun, J.; Hart, J.; Bissonnette, M.; Li, Y.C. Novel role of the vitamin D receptor in maintaining the integrity of the intestinal mucosal barrier. Am. J. Physiol. 2008, 294, G208-G216. [CrossRef] [PubMed]

11. Liu, P.T.; Stenger, S.; Tang, D.H.; Modlin, R.L. Cutting edge: Vitamin D-mediated human antimicrobial activity against Mycobacterium tuberculosis is dependent on the induction of cathelicidin. J. Immunol. 2007, 179, 2060-2063. [CrossRef] [PubMed]

12. Adorini, L. Tolerogenic dendritic cells induced by vitamin $\mathrm{D}$ receptor ligands enhance regulatory $\mathrm{T}$ cells inhibiting allograft rejection and autoimmune diseases. J. Cell. Biochem. 2003, 88, 227-233. [CrossRef] [PubMed]

13. Wintergerst, E.S.; Maggini, S.; Hornig, D.H. Contribution of selected vitamins and trace elements to immune function. Ann. Nutr. Metab. 2007, 51, 301-323. [CrossRef] [PubMed]

14. Soumelis, V.; Reche, P.A.; Kanzler, H.; Yuan, W.; Edward, G.; Homey, B.; Gilliet, M.; Ho, S.; Antonenko, S.; Lauerma, A.; et al. Human epithelial cells trigger dendritic cell-mediated allergic inflammation by producing TSLP. Nat. Immunol. 2002, 3, 673-680. [CrossRef] [PubMed]

15. Nanzer, A.M.; Chambers, E.S.; Ryanna, K.; Richards, D.F.; Black, C.; Timms, P.M.; Martineau, A.R.; Griffiths, C.J.; Corrigan, C.J.; Hawrylowicz, C.M. Enhanced production of IL-17A in patients with severe asthma is inhibited by $1 \alpha, 25$-dihydroxyvitamin $\mathrm{D}_{3}$ in a glucocorticoid-independent fashion. J. Allergy Clin. Immunol. 2013, 132, 297-304. [CrossRef] [PubMed]

16. Vassallo, M.F.; Camargo, C.A., Jr. Potential mechanisms for the hypothesized link between sunshine, vitamin D, and food allergy in children. J. Allergy Clin. Immunol. 2010, 126, 217-222. [CrossRef] [PubMed]

17. Perry, T.T.; Conover-Walker, M.K.; Pomés, A.; Chapman, M.D.; Wood, R.A. Distribution of peanut allergen in the environment. J. Allergy Clin. Immunol. 2004, 113, 973-976. [CrossRef] [PubMed]

18. Ministry of Health. Presenting Ethnicity: Comparing Prioritised and Total Response Ethnicity in Descriptive Analyses of New Zealand Health Monitor Surveys; Ministry of Health: Wellington, New Zealand, 2008.

19. Eyles, D.; Anderson, C.; Ko, P.; Jones, A.; Thomas, A.; Burne, T.; Mortensen, P.B.; Nørgaard-Pedersen, B.; Hougaard, D.M.; McGrath, J. A sensitive LC/MS/MS assay of $25 \mathrm{OH}$ vitamin $\mathrm{D}_{3}$ and $25 \mathrm{OH}$ vitamin $\mathrm{D}_{2}$ in dried blood spots. Clin. Chim. Acta 2009, 403, 145-151. [CrossRef] [PubMed] 
20. Bain, B. Dacie and Lewis Practical Haematology, 11th ed.; Churchill Livingstone: London, UK, 2011.

21. Ross, A.C.; Manson, J.E.; Abrams, S.A.; Aloia, J.F.; Brannon, P.M.; Clinton, S.K.; Durazo-Arvizu, R.A.; Gallagher, J.C.; Gallo, R.L.; Jones, G.; et al. The 2011 report on dietary reference intakes for calcium and vitamin D from the Institute of Medicine: What clinicians need to know. J. Clin. Endocrinol. Metab. 2011, 96, 53-58. [CrossRef] [PubMed]

22. Allergy New Zealand. What Is the Prevalence of Food Allergy in New Zealand; Allergy New Zealand: Auckland, New Zealand, 2014.

23. Osborne, N.J.; Koplin, J.J.; Martin, P.E.; Gurrin, L.C.; Lowe, A.J.; Matheson, M.C.; Ponsonby, A.L.; Wake, M.; Tang, M.L.; Dharmage, S.C.; et al. Prevalence of challenge-proven IgE-mediated food allergy using population-based sampling and predetermined challenge criteria in infants. J. Allergy Clin. Immunol. 2011, 127, 668-676. [CrossRef] [PubMed]

24. Oren, E.; Banerji, A.; Camargo, C.A., Jr. Vitamin D and atopic disorders in an obese population screened for vitamin D deficiency. J. Allergy Clin. Immunol. 2008, 121, 533-534. [CrossRef] [PubMed]

25. Peroni, D.G.; Piacentini, G.L.; Cametti, E.; Chinellato, I.; Boner, A.L. Correlation between serum 25-hydroxyvitamin D levels and severity of atopic dermatitis in children. Br. J. Dermatol. 2011, 164, 1078-1082. [CrossRef] [PubMed]

26. Lee, S.A.; Hong, S.; Kim, H.J.; Lee, S.H.; Yum, H.Y. Correlation between serum vitamin D level and the severity of atopic dermatitis associated with food sensitization. Allergy Asthma Immunol. Res. 2013, 5, $207-210$. [CrossRef] [PubMed]

27. Shin, Y.H.; Park, Y.H.; Sung, M.S.; Kim, S.W. Correlation between serum 25-hydroxyvitamin D levels and severity of atopic dermatitis in children. Allergy Asthma Respir. Dis. 2014, 2, 114-121. [CrossRef]

28. Wang, S.S.; Hon, K.L.; Kong, A.P.; Pong, H.N.; Wong, G.W.; Leung, T.F. Vitamin D deficiency is associated with diagnosis and severity of childhood atopic dermatitis. Pediatr. Allergy Immunol. 2014, 25, 30-35. [CrossRef] [PubMed]

29. Heimbeck, I.; Wjst, M.; Apfelbacher, C. Low vitamin D serum level is inversely associated with eczema in children and adolescents in Germany. Allergy 2013, 68, 906-910. [CrossRef] [PubMed]

30. Searing, D.A.; Zhang, Y.; Murphy, J.R.; Hauk, P.J.; Goleva, E.; Leung, D.Y. Decreased serum vitamin D levels in children with asthma are associated with increased corticosteroid use. J. Allergy Clin. Immunol. 2010, 125, 995-1000. [CrossRef] [PubMed]

31. Hammar, K.S.; Hedlin, G.; Konradsen, J.R.; Nordlund, B.; Kull, I.; Giske, C.G.; Pedroletti, C.; Söderhäll, C.; Melén, E. Subnormal levels of vitamin D are associated with acute wheeze in young children. Acta Paediatr. 2014, 103, 856-861. [CrossRef] [PubMed]

32. Menon, J.; Maranda, L.; Nwosu, B.U. Serum 25-hydroxyvitamin D levels do not correlate with asthma severity in a case-controlled study of children and adolescents. J. Pediatr. Endocrinol. Metab. 2012, 25, 673-679. [CrossRef] [PubMed]

33. Bener, A.; Ehlayel, M.S.; Tulic, M.K.; Hamid, Q. Vitamin D deficiency as a strong predictor of asthma in children. Int. Arch. Allergy Immunol. 2011, 157, 168-175. [CrossRef] [PubMed]

34. Ismail, A.M.; Aly, S.S.; Fayed, H.M.; Ahmed, S.S. Serum 25-hydroxyvitamin D and CD4 CD25 FoxP3 Regulatory $\mathrm{T}$ cell as Predictors of Severity of Bronchial Asthma in Children. Egypt. J. Immunol. 2015, 22, 9-18. [PubMed]

35. Uysalol, M.; Mutlu, L.C.; Saracoglu, G.V.; Karasu, E.; Guzel, S.; Kayaoglu, S.; Uzel, N. Childhood asthma and vitamin D deficiency in Turkey: Is there cause and effect relationship between them? Ital. J. Pediatr. 2013, 39, 78-86. [CrossRef] [PubMed]

36. Kerley, C.P.; Hutchinson, K.; Cormican, L.; Faul, J.; Greally, P.; Coghlan, D.; Elnazir, B. Vitamin $\mathrm{D}_{3}$ for uncontrolled childhood asthma: A pilot study. Pediatr. Allergy Immunol. 2016. [CrossRef] [PubMed]

37. Tachimoto, H.; Mezawa, H.; Segawa, T.; Akiyama, N.; Ida, H.; Urashima, M. Improved control of childhood asthma with low-dose, short-term vitamin D supplementation: A randomized, double-blind, placebo-controlled trial. Allergy 2016. [CrossRef] [PubMed]

38. Allen, K.J.; Koplin, J.J.; Ponsonby, A.-L.; Gurrin, L.C.; Wake, M.; Vuillermin, P.; Martin, P.; Matheson, M.; Lowe, A.; Robinson, M.; et al. Vitamin D insufficiency is associated with challenge-proven food allergy in infants. J. Allergy Clin. Immunol. 2013, 131, 1109-1116. [CrossRef] [PubMed] 
39. Baek, J.H.; Shin, Y.H.; Chung, I.H.; Kim, H.J.; Yoo, E.G.; Yoon, J.W.; Jee, H.M.; Chang, Y.E.; Han, M.Y. The Link between serum vitamin $\mathrm{D}$ level, sensitization to food allergens, and the severity of atopic dermatitis in infancy. J. Pediatr. 2014, 165, 849-854. [CrossRef] [PubMed]

40. Koplin, J.J.; Peters, R.L.; Ponsonby, A.-L.; Gurrin, L.C.; Hill, D.; Tang, M.L.K.; Dharmage, S.C.; Allen, K.J.; the HealthNuts Study Group. Increased risk of peanut allergy in infants of Asian-born parents compared to those of Australian-born parents. Allergy 2014. [CrossRef] [PubMed]

41. Cheng, H.M.; Kim, S.; Park, G.H.; Chang, S.E.; Bang, S.; Won, C.H.; Lee, M.W.; Choi, J.H.; Moon, K.C. Low vitamin D levels are associated with atopic dermatitis, but not allergic rhinitis, asthma, or IgE sensitization, in the adult Korean population. J. Allergy Clin. Immunol. 2014, 133, 1048-1055. [CrossRef] [PubMed]

42. Ehlayel, M.; Bener, A.; Sabbah, A. Is high prevalence of vitamin D deficiency evidence for asthma and allergy risks? Eur. Ann. Allergy Clin. Immunol. 2011, 43, 81-88. [PubMed]

43. Arshi, S.; Ghalehbaghi, B.; Kamrava, S.K.; Aminlou, M. Vitamin D serum levels in allergic rhinitis: Any difference from normal population? Asia Pac. Allergy 2012, 2, 45-48. [CrossRef] [PubMed]

44. Wjst, M.; Hyppönen, E. Vitamin D serum levels and allergic rhinitis. Allergy 2007, 62, 1085-1086. [CrossRef] [PubMed]

45. Baïz, N.; Dargent-Molina, P.; Wark, J.D.; Souberbielle, J.-C.; Annesi-Maesano, I.; EDEN Mother-Child Cohort Study Group. Cord serum 25-hydroxyvitamin D and risk of early childhood transient wheezing and atopic dermatitis. J. Allergy Clin. Immunol. 2014, 133, 147-153. [CrossRef] [PubMed]

46. Erkkola, M.; Kaila, M.; Nwaru, B.I.; Kronberg-Kippilä, C.; Ahonen, S.; Nevalainen, J.; Veijola, R.; Pekkanen, J.; Ilonen, J.; Simell, O.; et al. Maternal vitamin D intake during pregnancy is inversely associated with asthma and allergic rhinitis in 5-year-old children. Clin. Exp. Allergy 2009, 39, 875-882. [CrossRef] [PubMed]

47. Rothers, J.; Wright, A.L.; Stern, D.A.; Halonen, M.; Camargo, C.A., Jr. Cord blood 25-hydroxyvitamin D levels are associated with aeroallergen sensitization in children from Tucson, Arizona. J. Allergy Clin. Immunol. 2011, 128, 1093-1099. [CrossRef] [PubMed]

48. Heath, A.K.; Williamson, E.J.; Ebeling, P.R.; Kvaskoff, D.; Eyles, D.W.; English, D.R. Measurements of 25-hydroxyvitamin D concentrations in archived dried blood spots are reliable and accurately reflect those in plasma. J. Clin. Endocrinol. Metab. 2014, 99, 3319-3324. [CrossRef] [PubMed]

49. Larkin, E.K.; Gebretsadik, T.; Koestner, N.; Newman, M.S.; Liu, Z.; Carroll, K.N.; Minton, P.; Woodward, K.; Hartert, T.V. Agreement of blood spot card measurements of vitamin D levels with serum, whole blood specimen types and a dietary recall instrument. PLoS ONE 2011, 6, e16602. [CrossRef] [PubMed]

50. Newman, M.S.; Brandon, T.R.; Groves, M.N.; Gregory, W.L.; Kapur, S.; Zava, D.T. A liquid chromatography/tandem mass spectrometry method for determination of 25-hydroxy vitamin $\mathrm{D}_{2}$ and 25-hydroxy vitamin $\mathrm{D}_{3}$ in dried blood spots: A potential adjunct to diabetes and cardiometabolic risk screening. J. Diabetes Sci. Technol. 2009, 3, 156-162. [CrossRef] [PubMed]

51. Salmond, C.E.; Crampton, P.; Atkinson, J. NZDep2006 Index of Deprivation; Department of Public Health, University of Otago Wellington: Wellington, New Zealand, 2007.

52. Statistics New Zealand. 2013 Census. Available online: http://www.stats.govt.nz/Census/2013-census.aspx (accessed on 27 July 2014).

53. Sado, T.; Kamisakua, H.; Ikarashia, Y.; Kuboa, E. Immediate and long-term effects of radiation on the immune system of specific-pathogen-free mice. Int. J. Radiat. Biol. 1988, 53, 177-187. [CrossRef]

54. Allen, K.J.; Panjari, M.; Koplin, J.J.; Ponsonby, A.L.; Vuillermin, P.; Gurrin, L.C.; Greaves, R.; Carvalho, N.; Dalziel, K.; Tang, M.L.; et al. VITALITY trial: Protocol for a randomised controlled trial to establish the role of postnatal vitamin D supplementation in infant immune health. BMJ Open 2015, 5, e009377. [CrossRef] [PubMed]

(C) 2016 by the authors; licensee MDPI, Basel, Switzerland. This article is an open access article distributed under the terms and conditions of the Creative Commons Attribution (CC-BY) license (http://creativecommons.org/licenses/by/4.0/). 